\title{
Performance of 20w Solar Photovoltaic Module for Energy and Exergy Analysis
}

\author{
S. Yoga Sainath Reddy ${ }^{1} \mid$ Jagannath Reddy ${ }^{2} \mid$ Rajendra. $G^{3} \mid$ Sai Ranjith Reddy.K ${ }^{4} \mid$ Ganesh Kumar. I.R ${ }^{5}$
}

Department of Mechanical Engineering, RLJIT-Doddaballapura, Karnataka-561203

\section{To Cite this Article}

S. Yoga Sainath Reddy, Jagannath Reddy, Rajendra. G, Sai Ranjith Reddy.K and Ganesh Kumar. I.R. Performance of $20 \mathrm{w}$ Solar Photovoltaic Module for Energy and Exergy Analysis. International Journal for Modern Trends in Science and Technology 7, 102-106 (2021).

\section{Article Info}

Received on 15-April-2021, Revised on 02-May-2021, Accepted on 08-May-2021, Published on 14-May-2021.

\section{ABSTRACT}

The solar photovoltaic system generates both thermal energy and electrical energy by utilizing solar energy. In this paper an experimental attempt has made for calculating energy output as well as exergy output of solar PV panel installed at R.L.J.I.T. Bangalore. Energy and exergy analysis was performed by using first and second law of thermodynamics to evaluate energy and exergy. The framework involved in this process are ambient temperature, overall heat transfer, open-circuit voltage, short-circuit current, fill factor, solar radiations etc. It is predicted that temperature of $p v$ solar module has most effect on the efficiencies. By the help of water or air the heat can be removed to improve both energy and exergy efficiencies.

KEY WORDS: Solar PV module, electrical exergy, thermal exergy, electrical efficiency and exergy efficiency.

\section{INTRODUCTION}

According to last few decades consideration we are developing renewable energy sources as a replacement of conventional energy sources [1-2]. India is hallowed with profuse solar radiation. India lies between $6^{\circ}$ and $32^{\circ} \mathrm{N}$ latitudes. In a year 250-300 days are experienced with good sunlit weather. India has favourable climate conditions. Nowadays we are facing environmental challenges, especially global warming, resource depletion.

Except for water heating, solar energy technologies are not widely using. Solar cells converts $25 \%$ of irradiation into electrical energy. A solar cell is an electrical device which converts the light energy into electrical energy through the photovoltaic effect. When light reaches the $\mathrm{p}-\mathrm{n}$ junction, through very thin p-type layer the light photons can easily enter into the junction. Energy analysis is based on efficiency of energy potential and quantity of energy use, thus energy potential ignores in energy analysis. The max work potential obtained from the energy is exergy [3]. By many engineers exergy analysis is recognized for the evaluation of economic performance and thermodynamic performance of the thermodynamic system [4]. Exergy analysis is based on usable energy and availability of energy [5]. By using exergy analysis finding the energy utilization efficiency of an energy conversation system. Exergy analysis deals with maximum exergy delivery. Input and output of energy and exergy is evaluated for the performance of energy and exergy analyses of solar PV module. The analysis of solar water heating system and comparison of energy and exergy efficiencies are experimentally evaluated by Geng, Cenegal, and Turner [6]. For a sustainable future exergetic analysis and assessment of renewable energy sources was reviewed by Hepbasli [7].

The importance of this module is

1) To study the energy and exergy analysis of solar PV module and 
2) To identify the exergy losses in the solar PV

\section{METHODOLOGY}

\subsection{Energy efficiency of the solar PV module}

By using $1^{\text {st }}$ law of thermodynamics under a steady-state of an open system the exergy equation is given as

$\mathrm{Ex}_{\text {in }}=\mathrm{Ex}_{\mathrm{out}}(1)$

$E x_{\text {in }}-E_{x_{\text {out }}}=E x_{\text {loss }}(2)$

Equation (2) is a energy balance general equation. When Ex $x_{\text {in }}$ is supply energy for a system then $\mathrm{Ex}_{\text {out }}$ is the maximum amount of exergy obtained from that system. The amount of exergy consumed is less than the exergy loss also less. The energy efficiency is defined as the ratio of output power to input energy of thesolar PV module. On basis of solar isolation and surface temperature the output power and energy efficiency varies for the solar PV module. From the following equation, energy conversion efficiency (Sahin, Dincer, and Rosen 2007; Joshi, Dincer, and Reddy 2009) [8-9] is calculated for a solar PV module:

$\eta_{\text {energy }}=\frac{\text { Voc } \times \text { Isc } \times \text { FF }}{A \times G}$

Current and voltage of solar PV module in simple form:

$\mathrm{I}=\mathrm{I}_{1}-\mathrm{I}_{0} \times \exp ^{(\mathrm{q} \times(\mathrm{V}-\mathrm{IRs})) /(\mathrm{A} \times \mathrm{K} \times \mathrm{T})}$.

Electric power output of solar PV module:

$\mathrm{P}_{\mathrm{el}}=\mathrm{I} \times \mathrm{V}$.

Maximum power output of solar PV module:

$\mathrm{P}_{\max }=\mathrm{V}_{\mathrm{oc}} \times \mathrm{I}_{\mathrm{sc}} \times \mathrm{FF}=\mathrm{V}_{\mathrm{mp}} \times \mathrm{I}_{\mathrm{mp}}$ (6)

The solar PV module is converted the solar energy into electrical energy and thermal energy, by neglecting convection, conduction and radiation. As more the top surface temperature increases, the solar PV efficiency decreases. By supplying water or air the solar PV module can be cooled to get more efficiency (Duffie and Beek-man 1991) [10].

\subsection{Exergy efficiency of the solar PV module}

Exergy analysis includes the quality of energy, which allows use of the energy potential [11]. For a solar PV module the overall exergy balance equation under a steady flow (Wong 2000) [12] is

Exergy In = Exergy Out + Exergy Loss + Irreversibility.

The ratio of exergy output to the exergy input is known as exergy efficiency [14].

$\eta_{\mathrm{ex}}=\frac{\text { Ex output }}{\text { Ex input }}$.

Input exergy of a solar PV module:

It includes only solar radiation intensity exergy which effects on solar PV module [15-16] is given by

$\mathrm{E}_{\mathrm{x}}$ in $=\mathrm{AG}\left[1-\frac{4}{3}\left(\frac{\mathrm{Tab}}{\mathrm{Tsun}}\right)+\frac{1}{3}\left(\frac{\mathrm{Tab}}{\mathrm{Tsun}}\right)^{4}\right]$.

Output exergy of a solar PV module:

It is calculated as [17] out let of PV modules include thermal exergy and electrical exergy

$\mathrm{E}_{\mathrm{x}}$ out $=\mathrm{E}_{\mathrm{x}}$ thermal $+\mathrm{E}_{\mathrm{x}}$ electrical. (10) module.

Thermal exergy of a solar PV module:

$\mathrm{E}_{\mathrm{x}}$ Thermal $=\mathrm{Q}[1-\mathrm{Ta} / \mathrm{Tm}]$.

$\mathrm{Q}=\mathrm{UA}\left(\mathrm{T}_{\mathrm{m}}-\mathrm{T}_{\mathrm{a}}\right)$.

Overall heat loss coefficient of a solar PV module:

Overall heat loss coefficient of PV module [18] depends on the convection and radiation

$\mathrm{U}=\mathrm{h}_{\text {conv }}+\mathrm{h}_{\text {rad }}$.

Coefficient of connective heat transfer [19] of solar PV module:

$\mathrm{H}_{\text {conv }}=2.8+3 \mathrm{~V}_{\mathrm{w}}$.

Coefficient radiation heat transfer [20]:

$\mathrm{H}_{\mathrm{rad}}=\varepsilon \sigma\left(\mathrm{T}_{\mathrm{sky}}+\mathrm{T}_{\mathrm{m}}\right)\left(\mathrm{T}_{\text {sky }}{ }^{2}+\mathrm{T}_{\mathrm{m}}^{2}\right)$.

Temperature of sky:

$\mathrm{T}_{\text {sky }}=\mathrm{T}_{\mathrm{a}}-6$.

According to NOCT value temperature of the solar PV module:

$\mathrm{T}_{\mathrm{m}}=\mathrm{T}_{\mathrm{a}}+(\mathrm{NOCT}-20) \frac{\mathrm{G}}{800}$.

Electrical exergy of solar PV module [21]:

$\mathrm{Ex}$ electrical $=\mathrm{V}_{\mathrm{oc}} \times \mathrm{I}_{\mathrm{sc}} \times \mathrm{FF}$.

\subsection{Experimental study}

The experimental study was done in the south region of India. The location lies in $13^{\circ} 17^{\prime} 50.28^{\prime \prime} \mathrm{N}$ Latitude and $77^{\circ} 32$ ' $18.24^{\prime \prime} \mathrm{E}$ Longitude. The ambient temperature varying between $10^{\circ}-40^{\circ} \mathrm{C}$ during a year in Bangalore. The solar PV module was experiencedunder some parameterssuch as $\mathrm{V}_{\mathrm{oc}}, \mathrm{I}_{\mathrm{sc}}, \mathrm{V}_{\mathrm{w}}, \mathrm{T}_{\mathrm{a}}$ and solar irradiance etc. The module was tested under the time interval of 9:00am to 16:00 pm. By using anemometer the wind velocity was measured and ambient temperature was measured by using temperature indicator. Below tables 1-3 list the specifications of module and the parameters which are analysed.

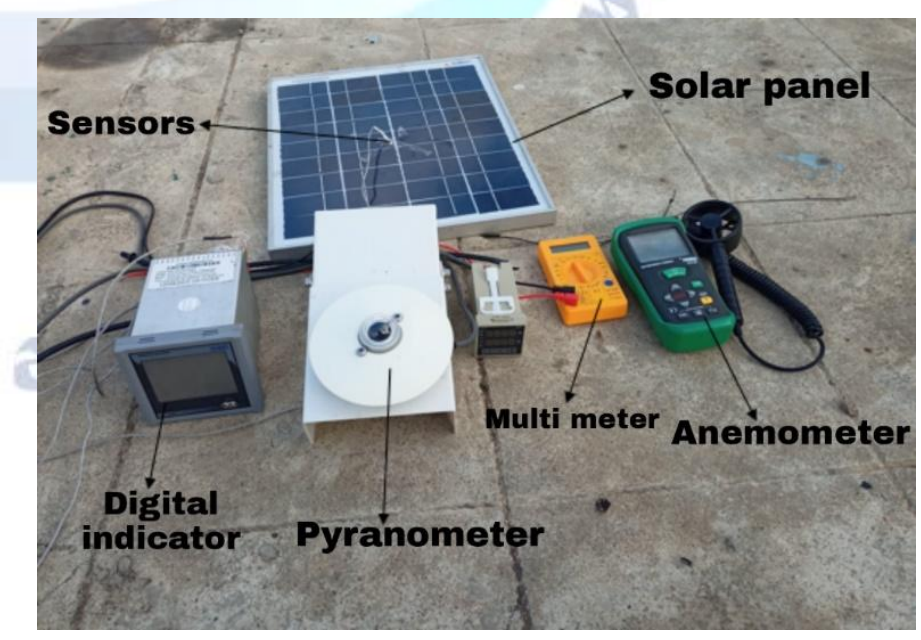

Figure 1: 20W solar PV module at R.L.J.I.T, Doddaballapura. 
2.4 Input parameter and specification of the solar PV module

Table 1. Input parameters involved in this process.

\begin{tabular}{ll}
\hline Input parameters & Value \\
\hline NOCT & $41^{\circ} \mathrm{C}$ \\
$\sigma$ & $5.67 \times 10^{-8} \mathrm{~W} / \mathrm{m}^{2} \mathrm{~K}$ \\
$\varepsilon$ & 0.9 \\
Sun temperature & $5780 \mathrm{~K}$ \\
\hline
\end{tabular}

Table 2. Specifications of the solar PV module.

\begin{tabular}{ll}
\hline Model & ECO 020 \\
\hline Maximum power & $20 \mathrm{~W}$ \\
Open-circuit voltage & $21.6 \mathrm{~V}$ \\
Short-circuit voltage & $1.29 \mathrm{~A}$ \\
Maximum voltage & $600 \mathrm{~V}$ \\
Dimensions & $449 \times 354 \mathrm{X} 21$ \\
Weight & $2.31 \mathrm{Kg}$ \\
Fill factor & 1.19 \\
\hline
\end{tabular}

\section{RESULTS AND DISCUSSION}

The experimental data was obtained in the month of January, the research was carried out at R.L.J.I.T, Doddaballapur, Bangalore, India. In the latitude of $13.2957^{\circ} \mathrm{N}$ and longitude of $77.5364^{\circ} \mathrm{E}$. This experiment is carried on a clear day in January respectively. Exergy efficiency is calculated by using second law of thermodynamics. Based on experimental study exergy analysis is important in the study of the solar photovoltaic panel.

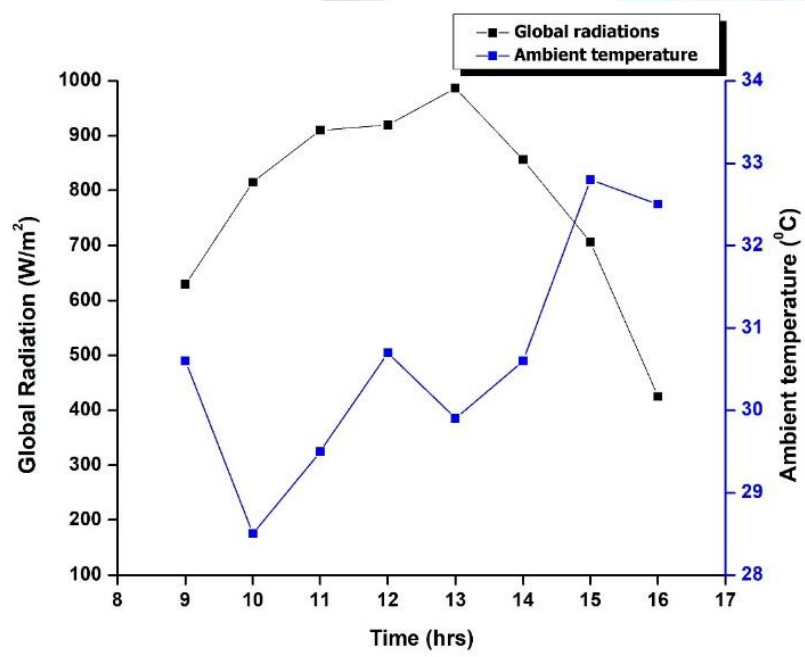

Figure 2: Variations of solar radiation, ambient temperature and time

The variation of solar radiation intensity during the test day is shown in above fig. The solar radiations are varied from $629 \mathrm{~W} / \mathrm{m}^{2}-987 \mathrm{~W} / \mathrm{m}^{2}$. As the solar radiation increases the solar cell temperature increases which results to decrease in efficiency.

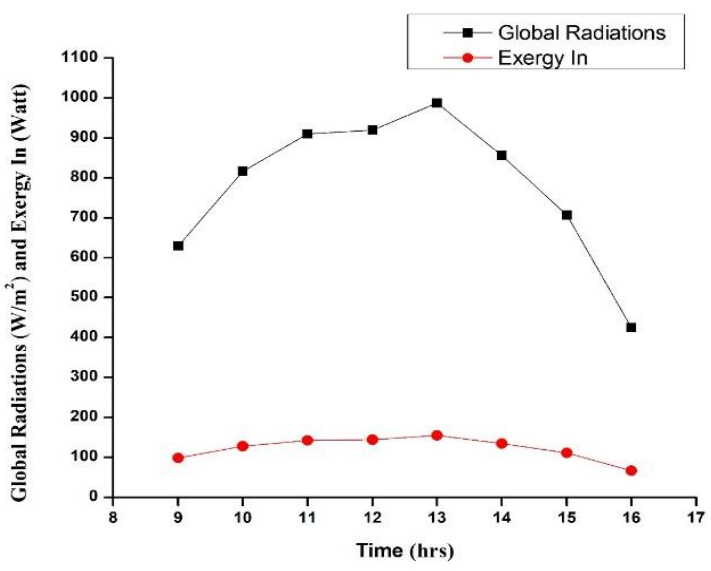

Figure 3: variations of solar radiations and exergy in The radiations of solar intensity and exergy in is shown in above fig. The exergy in varies from 80.18 and 188.19. The solar radiations are based on the ambient temperature

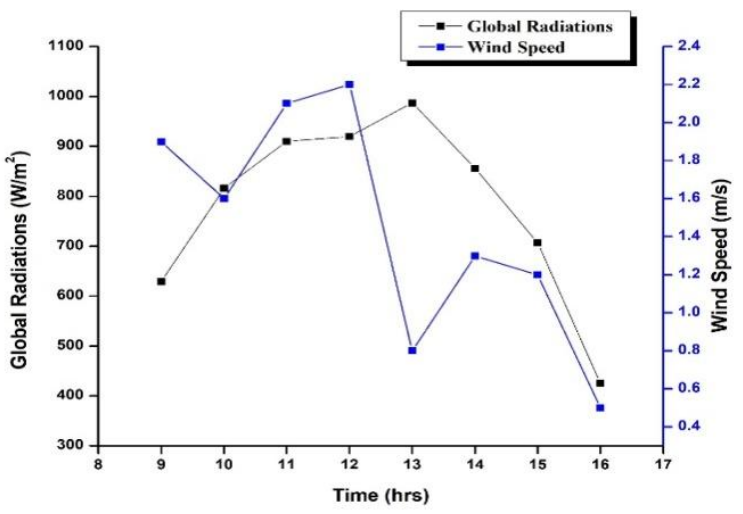

Figure: 4 variations of global radiations and wind velocity

The variations between global radiations and wind velocity is shown in above fig. The wind speed varies between $0.5 \mathrm{~m} / \mathrm{s}$ to $2.2 \mathrm{~m} / \mathrm{s}$. And the global radiations varies between $425 \mathrm{~W} / \mathrm{m}^{2}$ to $987 \mathrm{~W} / \mathrm{m}^{2}$. Due to the variations in wind speed the heat transfer changes between surface of module and surroundings.

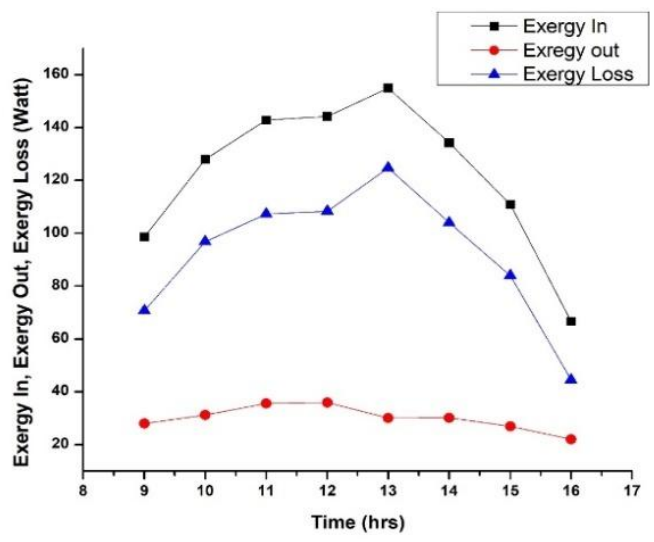

Figure: 5 variations between Exergy in, Exergy out, and Exergy loss. 
Above fig shows the variations between exergy in, exergy out, and exergy loss. The exergy in varies from $66.65 \mathrm{~W}$ to $144.33 \mathrm{~W}$, the exergy out varies from $22.101 \mathrm{~W}$ to $35.97 \mathrm{~W}$, and the exergy loss varies from $44.54 \mathrm{~W}$ to $108.35 \mathrm{~W}$.

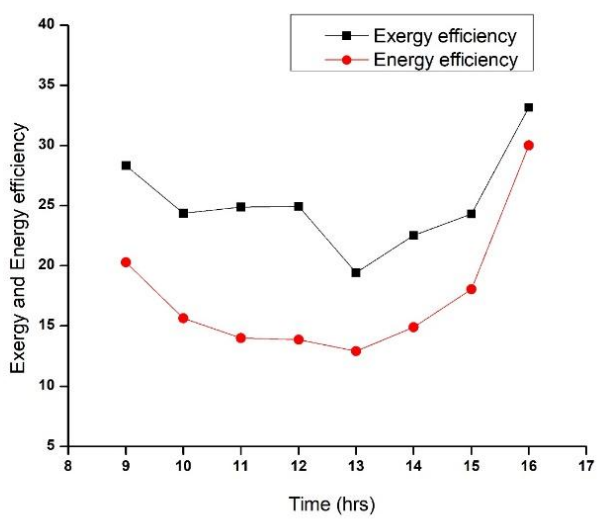

Figure 6: Energy and exergy efficiency of the PV module

The above fig shows the variation between exergy efficiency and energy efficiency. Exergy efficiency decreases on the basis of temperature. By cooling the PV module the exergy efficiency increases.

\section{CONCLUSION}

In this study, an exergy and energy analysis of 20W solar photovoltaic module was conducted at RLJIT, Doddaballapur, Bangalore rural, India. A research study had been conducted to investigate the performance of $20 \mathrm{~W}$ solar photovoltaic module. The experimental results were obtained through accurate measurement of different parameter during a sunny day in January 2021. The data obtained is used to find the maximum exergy efficiency and losses of exergy and the optimum temperature also calculated. The following conclusions are taken from this experimental study.

1) The outcome result shows that the PV module have a minimum exergy efficiency $\left(\eta_{\mathrm{ex}}=42.2 \%\right)$ with respect to the solar PV module.

2) The ambient temperature increases as PV exergy decreases due to increasing in cell temperature and output electricity also increases.

3) The exergy efficiency increases due to solar radiation increases at beginning and then reduces after reaching the maximum point.

4) Research and development are focused in the direction of low cost semiconductor material and improving the efficiency of solar module and reducing the cost of solar PV electricity.

\section{Acknowledgement}

We are very thankful to management and Principal Dr. M. Sreenivasa Reddy of R.L. Jalappa Institute of Technology Doddaballapura, Banglore-India for providing us all the support to complete this research work and regards to my guide Assistant professor Mr. Jagannath Reddy and I appreciate to staff members in mechanical department for supporting me to conduct the experiment.

\section{NOMENCLATURE}

\begin{tabular}{|c|c|}
\hline I & Current (A) \\
\hline$I_{\mathrm{sc}}$ & Short-circuit current (A) \\
\hline$I_{\mathrm{mp}}$ & Current at maximum power point (A) \\
\hline $\mathrm{V}$ & Voltage (V) \\
\hline $\mathrm{V}_{\mathrm{oc}}$ & Open-circuit voltage (V) \\
\hline $\mathrm{V} \mathrm{mp}$ & Voltage at maximum power point \\
\hline$\eta$ energy & Energy efficiency \\
\hline $\mathrm{I}_{\mathrm{I}}$ & Light generated current (A) \\
\hline $\mathrm{I}_{\mathrm{o}}$ & Saturation current density (A) \\
\hline $\mathrm{FF}$ & Fill factor \\
\hline q & Charge of electron (ev) \\
\hline $\mathrm{R}_{\mathrm{s}}$ & Series resistance (ohm) \\
\hline A & Surface area of the module $\left(\mathrm{m}^{2}\right)$ \\
\hline G & Global irradiance $\left(\mathrm{W} / \mathrm{m}^{2}\right)$ \\
\hline $\mathrm{K}$ & Boltzmann constant $(\mathrm{J} / \mathrm{K})$ \\
\hline $\mathrm{P}$ el & Electrical power $(\mathrm{W})$ \\
\hline $\mathrm{P}_{\max }$ & maximum power $(\mathrm{W})$ \\
\hline $\mathrm{Ex}$ in & input exergy (W) \\
\hline Ex loss & exergy loss (W) \\
\hline Ex out & output exergy (W) \\
\hline Ex thermal & thermal exergy (W) \\
\hline Ex electrical & electrical exergy (W) \\
\hline $\mathrm{T}$ & temperature $(\mathrm{K})$ \\
\hline $\mathrm{T}_{\mathrm{a}}$ & ambient temperature $(\mathrm{K})$ \\
\hline $\mathrm{T}_{\mathrm{s}}$ & surface temperature of the sun $(\mathrm{K})$ \\
\hline $\mathrm{T}_{\mathrm{m}}$ & module temperature $(\mathrm{K})$ \\
\hline $\mathrm{T}_{\text {sky }}$ & sky temperature $(\mathrm{K})$ \\
\hline Q & heat emitted to the surroundings (W) \\
\hline $\mathrm{U}$ & overall heat loss coefficient $\left(\mathrm{W} / \mathrm{m}^{2} \mathrm{~K}\right)$ \\
\hline $\mathrm{h}_{\text {conv }}$ & convective heat transfer coefficient $\left(\mathrm{W} / \mathrm{m}^{2} \mathrm{~K}\right)$ \\
\hline $\mathrm{h}_{\mathrm{rad}}$ & radiative heat transfer coefficient $\left(\mathrm{W} / \mathrm{m}^{2} \mathrm{~K}\right)$ \\
\hline $\mathrm{V}_{\mathrm{w}}$ & wind velocity (m/s) \\
\hline$\sigma$ & Stefan Boltzmann's constant $\left(\mathrm{W} / \mathrm{m}^{2} \mathrm{~K}^{4}\right)$ \\
\hline$\varepsilon$ & emissivity of the module \\
\hline NOCT & nominal operating cell temperature $\left({ }^{\circ} \mathrm{C}\right)$ \\
\hline
\end{tabular}

\section{REFERENCES}

[1] K H Solangi, Islam MR, Saidur R, Rahim NA, Fayaz H, A review on global solar energy Policy, Renewable and Sustainable Energy Reviews 15(4) (2011) 2149-63.

[2] S Mekhilef, R Saidur, A Safari, A review on solar energy use in industries, Renewable and Sustainable Energy Reviews 15(4) (2011): 1777-90/ 
[3] A. Bejan, Advanced engineering thermodynamics, New York: Wiley Interscience Publishers (1988).

[4] Y.A. Cengel, M.A. Boles, Thermodynamics: An Engineering Approach, $5^{\text {th }}$ Edition New York: Tata McGraw Hill (2006).

[5] M. A Rosen, F. C. Hopper and L. N. Barbaris, Exergy analysis for the evaluation of the performance of closed thermal energy storage systems, Transactions of the ASME, Journal of Solar Energy Engineering 110, (188) 255-261

[6] D. L. Larson and L. A. B. Cortez, Exergy analysis: essential to effective energy management, Transactions of the ASAE 38(4) (1995) 1173-1178.

[7] L. Geng, Y.A. Cengel, R.H. Turner, Exergy analysis of a solar heating system, Journal of Solar Energy Engineering 117 (3) (1995) 249-251.

[8] A. Hepabsli, A key review on exergetic analysis and assessment of renewable energy resources for a sustainable future, Renewable and Sustainable Energy Reviews [J], 12 (2008) 593-661.

[9] A.D. Sahin, I. Dincer and M. A. Rosen, Thermodynamic analysis of solar photovoltaic cell systems, Solar Energy Materials \& Solar Cells, 91 (2007) 153-159.

[10] A.S. Joshi, I. Dincer and B. V. Reddy, Development of solar exergy maps, International Journal of Energy Resources 33 (209) 709-718.

[11] Duffie, J. A., and W. A. Beckman. 1991. Solar Engineering of Thermal Processes. $2^{\text {nd }}$ ed. New York: Wiley.

[12] K. F. V. Wong, Thermodynamis for engineers, University of Miami, CRC Press LLC (2000).

[13] Wong, K. F. V. 2000. Thermodynamics for Engineers. University of Miami, Boca Raton, Fla, USA: CRC Press LLC.

[14] A. Hepabsli, A key review on exergetic analysis and assessment of renewable energy resources for a sustainable future, Renwable and Sustainable Energy Reviews [J], 12 (2008) 593-661.

[15] R. Petela, Exergy of undiluted thermal radiation, Solar Energy, 74, (2003), 469-488.

[16] T.J. Kotas, The exergy method of thermal plant analysis, Malabar, FL: Krieger Publish Company (1995).

[17] R. Petela, An approach to the exergy analysis of photosynthesis, Solar Energy, 82, 2008, 311-328.

[18] F. Sarhaddi, S. Farahat, H. Ajam, A. Behzadmehr, Exergetic Performance Evaluation of a Solar Photovoltaic (PV) Array, Australian Journal of Basic and Applied Sciences, 4(3) (2010) 502-519.

[19] G. Boyle, 004, "Renewable energy power for a sustainable future." Second ed., Oxford University Press, Oxford.

[20] J. H. Watmuff, W. W. S. Charters and D. Proctor, Solar and wind induced external coefficients for solar collectors. COM PLES 2 ${ }^{\text {nd }}$ Quarter. (1977) 56. 2, 56.

[21] S.P. Sukhatme, Solar energy, Mc Graw-Hill, (1993) 83-139.

[22] A.S. Joshi, I. Dincer and B. V. Reddy, Thermodynamic assessment of photovoltaic systems. Solar Energy, 83(8) (2009) 1139-1149.

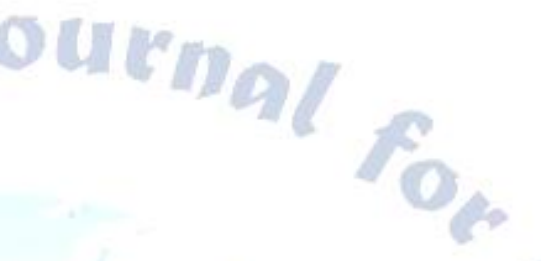

